\title{
Say the Months in Reverse Order
}

National Cancer Institute

\section{Source}

National Cancer Institute. Say the Months in Reverse Order. NCI Thesaurus. Code

C110933.

A request that an individual say the months of the year in reverse order. 